УДК 621.3.049.77

ББК 22.379

\title{
THE AGgREgATION PROCESS AS A CAUSE OF LARGE-SCALE DISORDER IN NANOCOMPOSITES OF POLYMER/ORGANOCLAY
}

\author{
Kozlov Georgiy Vladimirovich \\ Senior Researcher, \\ Kabardino-Balkarian State University named after H.M. Berbekov \\ I_dolbin@mail.ru \\ Chernyshevskogo St., 175, 360004 Nalchik, Russian Federation \\ Zaikov Gennadiy Efremovich \\ Doctor of Chemical Sciences, Professor, Head of Department of Biological \\ and Chemical Physics of Polymers, Institute of Biochemical Physics named after N.M. Emanuel of RAS \\ chembio@sky.chph.ras.ru \\ Kosygina St., 4, 119334 Moscow, Russian Federation
}

\section{Mikitaev Abdulla Kasbulatovich}

Doctor of Chemical Sciences, Professor,

Kabardino-Balkarian State University named after H.M. Berbekov

I_dolbin@mail.ru

Chernyshevskogo St., 175, 360004 Nalchik, Russian Federation

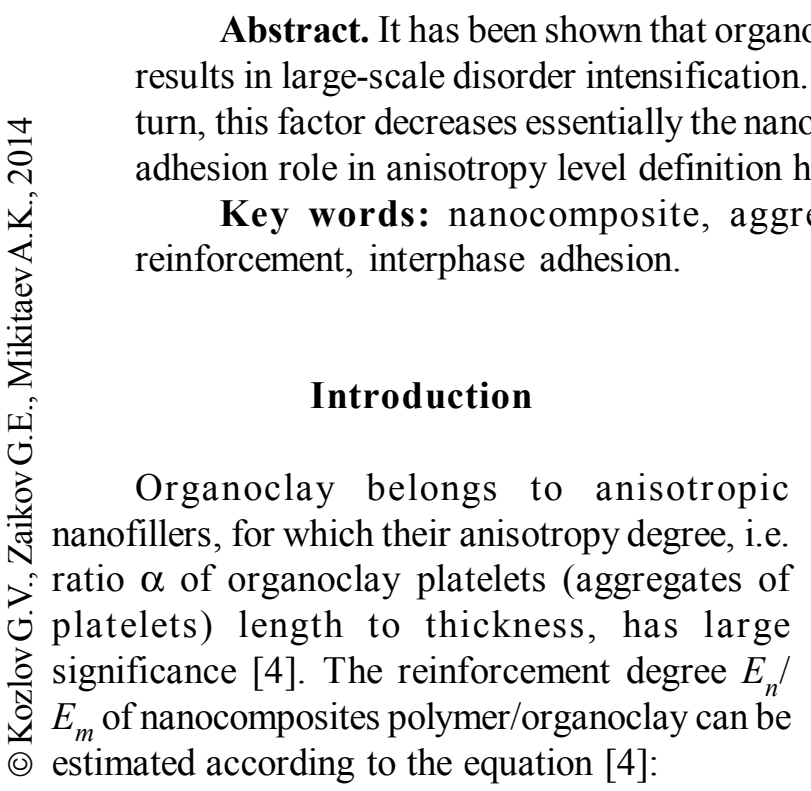

$$
\frac{E_{n}}{E_{m}}=1+2 \alpha C_{a} \varphi_{n},
$$

where $E_{n}$ and $E_{m}$ are elasticity moduli of nanocomposite and matrix polymer, respectively, $C_{a}$ is an orientation factor, which is equal for organoclay to about 0.5 [4], $\varphi_{n}$ is organoclay volume content.

In case of organoclay platelets aggregation, i.e. their "packets" (tactoids) formation [3], the 
increase of such "packets" thickness takes place in comparison with a separate platelet, that results in the reduction of length/thickness ratio $\alpha$ at platelet constant length and, as consequence, the decrease of nanocomposites reinforcement degree is realized according to the equation (1). The present work purpose is the analytical study of organoclay aggregation, i. e. large-scale disorder, influence on reinforcement degree on the example of nanocomposites plasticate of poly(vinyl chloride) - organomodified montmorillonite.

\section{Experimental}

The plasticate of poly(vinyl chloride) (PVC) of mark U30-13A, prescription 8/2 GOST 596072 was used as a matrix polymer. The modification product of montmorillonite (MMT) of deposit Gerpegezh (KBR, Russian Federation), modified by urea with content of 10 mass \% with cationchanging capacity of $95 \mathrm{mg}$-eq/100 g of clay was applied as a nanofiller. Organoclay content was varied within the limits of $1-10$ mass $\%$.

The nanocomposites PVC-MMT preparation was performed as follows. The components were mixed in a two-speed Diosna blender R 600/HC 2500 , the design of which ensures intensive intermixing in turbulent regime with blends high homogenization and hot air blowing. After components intensive intermixing the composition was cooled up to temperature $313 \mathrm{~K}$ and processed on a twin screw extruder Thermo Haake, model Reomex RTW 25/42, production of German Federal Republic, at temperature 418-438 K and screw rotation speed of $48 \mathrm{rpm}$.

Sheet nanocomposite was obtained by a hot rolling method at temperature $(433 \pm 10) \mathrm{K}$ during 5-15 min. The samples in the shape of a two-sided spade with sizes according to GOST 112 62-80 were cut out by punch. Uniaxial tension mechanical tests have been performed on the universal testing apparatus Gotech Testing Machine CT-TCS 2000, production of German Federal Republic, at temperature $293 \mathrm{~K}$ and strain rate of $\sim 2 \times 10^{-3} \mathrm{~s}^{-1}$.

\section{Results and discussion}

The nanofiller initial particles aggregation is the main process, enhancing large-scale disorder level in polymer nanocomposites. For each nanofiller type this process has its specific character, but in case of anisotropic nanofillers (organoclay, carbon nanotubes) application this process always decreases their anisotropy degree, i. e. aspect ratio $\alpha$, that reduces nanocomposites reinforcement degree according to the equation (1). Let us consider the physical bases of the value $\alpha$ reduction at organoclay content increasing in the considered nanocomposites. As it is known [2], organoclay platelets number $\mathrm{N}_{p l}$ in "packet" (tactoid) can be determined as follows:

$$
N_{p l}=24-5.7 b_{\alpha},
$$

where $b_{\alpha}$ is the dimensionless parameter, characterizing the level of interfacial adhesion polymeric matrixnanofiller, which is determined with the aid of the following percolation relationship [3]:

$$
\frac{E_{n}}{E_{m}}=1+11\left(c \varphi_{n} b_{\alpha}\right)^{1.7}
$$

where $\mathrm{c}$ is constant coefficient, which is equal to 1.955 for intercalated organoclay and 2.90 - for exfoliated one.

In its turn, the value $\varphi_{\mathrm{n}}$ can be determined according to the well-known formula [3]:

$$
\varphi_{n}=\frac{W_{n}}{\rho_{n}},
$$

where $\mathrm{W}_{\mathrm{n}}$ is nanofiller mass content; $\rho_{\mathrm{n}}$ is its density, which for nanoparticles is determined as follows [3]:

$$
\rho_{n}=188\left(D_{p}\right)^{1 / 3}, \mathrm{~kg} / \mathrm{m}^{3},
$$

where $\mathrm{D}_{\mathrm{p}}$ is the initial nanoparticle diameter, which is given in $\mathrm{nm}$.

In case of organoclay parameter $D_{p}$ is determined as arithmetical means of its three basic sizes: length, width and thickness, which are equal to 100,35 and $0.65 \mathrm{~nm}$, respectively [5].

An alternative method of the value $\mathrm{N}_{\mathrm{pl}}$ estimation gives the following equation [5]:

$$
\chi=\frac{N_{p l} d_{p l}}{\left(N_{p l}-1\right) d_{001}+d_{p l}},
$$

where $\chi$ is relative volume content of montmorillonite in tactoid («effective particle» [5]); $\mathrm{d}_{\mathrm{pl}}$ is thickness of 
organoclay separate platelet; $\mathrm{d}_{001}$ is interlayer spacing, i.e. the distance between organoclay platelets in tactoid, which can be estimated according to the following formula [2]:

$$
d_{001}=1.27 b_{\alpha}, \mathrm{nm} .
$$

In its turn, parameter $\mathrm{c}$ is determined as follows [2]:

$$
\chi=\frac{\varphi_{n}}{\varphi_{n}+\varphi_{i f}}
$$

where $\varphi_{\text {if }}$ is a relative fraction of interfacial regions in nanocomposite, estimated with the aid of the following percolation relationship [3]:

$$
\frac{E_{n}}{E_{m}}=1+11\left(\varphi_{n}+\varphi_{i f}\right)^{1.7} .
$$

The comparison of $\mathrm{N}_{p l}$ value calculations according to the equations (2) and (6) showed their close correspondence.

In Fig. 1 the dependence of $\mathrm{N}_{\mathrm{pl}}\left(\varphi_{\mathrm{n}}\right)$ for nanocomposites PVC/MMT is adduced. As one can see, at quite enough small values $\varphi_{n} \leq 0.05$ fast growth of $\mathrm{N}_{\mathrm{pl}}$ occurs, i.e. strong aggregation of organoclay initial platelets, and at $\varphi_{\mathrm{n}}>0.05$ the value $\mathrm{N}_{p l}$ achieves the asymptotic branch: $\mathrm{N}_{\mathrm{pl}} \approx 22$. As it was noted above, the reduction of nanofiller anisotropy degree, characterized by parameter $\alpha$, was defined by its aggregation, the level of which could be characterized by parameter $\mathrm{N}_{\mathrm{pl}}$. In Fig. 2

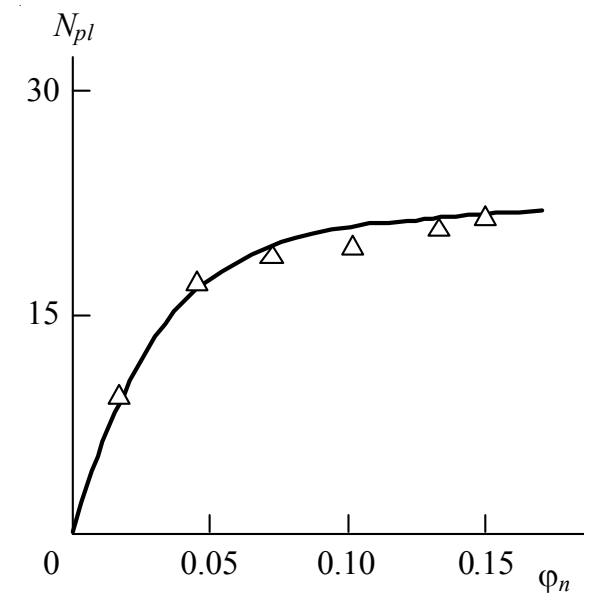

Fig. 1. The dependence of organoclay platelets number per one tactoid $\mathrm{N}_{\mathrm{pl}}$ on nanofiller volume content $\varphi_{\mathrm{n}}$ for nanocomposites PVC-MMT

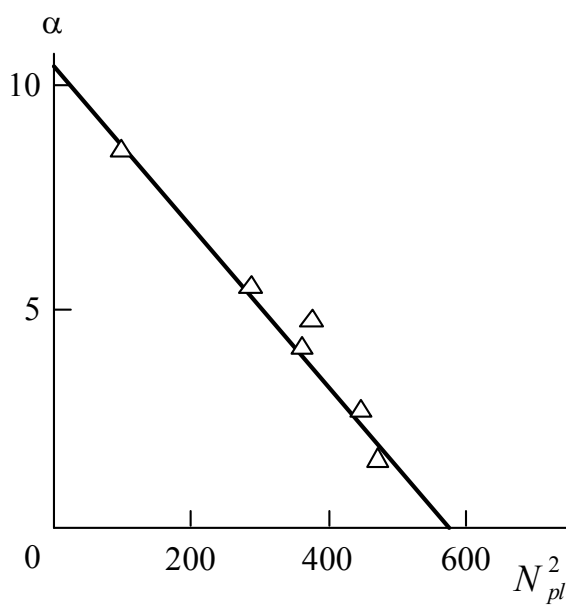

Fig. 2. The dependence of organoclay anisotropy degree $\alpha$ on its platelets number per one tactoid $\mathrm{N}_{p l}$ for nanocomposites PVC-MMT 


\section{ТЕХНИКО-ТЕХНОЛОГИЧЕСКИЕ ИННОВАЦИИ}

the dependence $\alpha\left(N_{p l}^{2}\right)$ for the considered nanocomposites, where quadratic shape of dependence was chosen with the purpose of its linearization. As it was expected, the reduction of organoclay anisotropy degree, characterized by the parameter a, is observed at its platelets aggregation, characterized by the value $\mathrm{N}_{\mathrm{pl}}$, enhancement, which is expressed analytically by the following equation:

$$
\alpha=10.5-0.018 N_{p l}^{2},
$$

where the value a was estimated according to the equation (1).

Theoretical method of parameter $\alpha\left(\alpha^{\mathrm{T}}\right)$ estimation can be obtained as follows. Organoclay aggregates (tactoids) anisotropy degree can be determined according to the equation:

$$
\alpha^{T}=\frac{L_{p l}}{t_{\text {org }}},
$$

where $\mathrm{L}_{\mathrm{pl}}$ is organoclay platelet length, which is equal to $\sim 100 \mathrm{~nm}[3], \mathrm{t}_{\text {org }}$ is its tactoid thickness. follows:

In its turn, the value $t_{\text {org }}$ is determined as

$$
t_{\text {org }}=d_{001} N_{p l}+1 .
$$

Besides, it should be born in mind, that experimental value $\alpha$ in the equation (1) is determined on the basis of reinforcement degree $\mathrm{E}_{n} / \mathrm{E}_{m}$, i. e. on the basis of mechanical tests results. This means that value $\alpha$ depends on conditions of stress transfer on interfacial boundary polymeric matrix-organoclay, i.e. on the parameter $b_{\alpha}$ value. Then parameter $\alpha^{T}$ can be determined finally as follows:

$$
\alpha^{T}=\frac{L_{p l} b_{\alpha}}{1.27 b_{\alpha} N_{p l}+1} .
$$

In Fig. 3 the comparison of experimental a and calculated according to the equation (13) $\alpha^{T}$ values of organoclay tactoids aspect ratio, characterizing large-scale disorder level for the considered nanocomposites, is adduced. As one can see, good enough correspondence of experiment and theory is obtained (average discrepancy of $\alpha$ and $\alpha^{T}$ makes up $\sim 9 \%$ ).

The equations (10) and (13) allow to predict reinforcement degree $\mathrm{E}_{n} / \mathrm{E}_{m}$ on organoclay with known structural characteristics. In Fig. 4 the comparison of theoretical curves $\mathrm{E}_{n} / \mathrm{E}_{m}\left(\varphi_{n}\right)$, calculated according to the equation (1), where parameter $\alpha^{\mathrm{T}}$ was determined according to the formulas (10) and (13), and the corresponding experimental data is adduced. As one can see, a good both qualitative (the theoretical curves are reflected experimental dependence maximum without existence of maximums for parameters $\mathrm{N}_{p l}$ and $\mathrm{d}_{001}$ ) and quantitative correspondence of theory and experiment (their average discrepancy makes up less $2.5 \%$ ).

Let us consider in conclusion the influence of organoclay platelets aggregation or large-scale

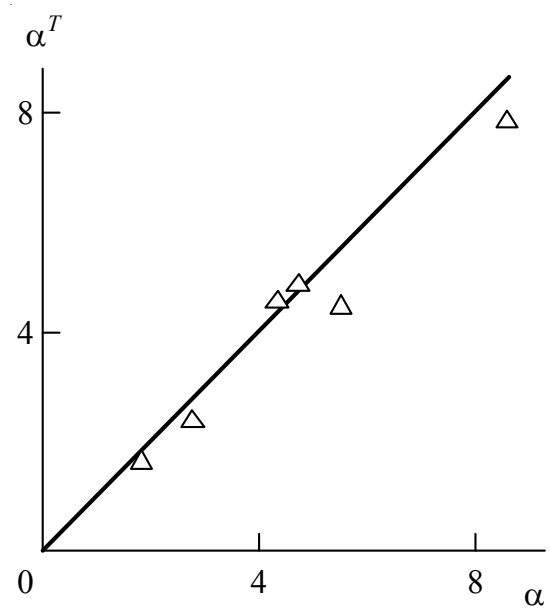

Fig. 3. The comparison of experimental $\alpha$ and calculated according to the equation (13) $\alpha^{T}$ organoclay anisotropy degree for nanocomposites PVC-MMT 


\section{ТЕХНИКО-ТЕХНОЛОГИЧЕСКИЕ ИННОВАЦИИ}

disorder on the considered nanocomposites reinforcement degree. In Fig. 5 the experimental and calculated according to the equation (1) at organoclay aggregation minimum level $\left(\mathrm{N}_{p l}=9.70\right.$, $\mathrm{b}_{\alpha}=2.51, \alpha=8.6$ ), corresponding to organoclay content $\mathrm{W}_{\mathrm{n}}=1$ mass $\%$, dependences $\mathrm{E}_{n} / \mathrm{E}_{m}\left(\varphi_{n}\right)$ for nanocomposites PVC/MMT are adduced. As it follows from this comparison, both lower values of reinforcement degree and its decay at $\mathrm{W}_{n}>7$ mass $\%$ are due precisely to organoclay platelets aggregation in "packets" (tactoids).

\section{Conclusions}

Thus, the present work results have demonstrated that organoclay platelets aggregation in "packets" (tactoids) causes large- scale disorder enhancement, that reduces nanofiller anisotropy degree. In its turn, this factor decreases essentially reinforcement degree (or elasticity modulus) of nanocomposites polymerorganoclay. Moreover, in case of large organoclay content (>7 mass \%), reinforcement degree reduction at nanofiller content growth is observed. The important role of interfacial adhesion in anisotropy level determination has been shown.

\section{REFERENCES}

1. Schaefer D.W., Justice R.S. How Nano are Nanocomposites? Macromolecules, 2007, vol. 40, no. 24, pp. 8501-8517.

2. Mikitaev A.K., Kozlov G.V., Zaikov G.E. Polymer Nanocomposites: Variety of Structural

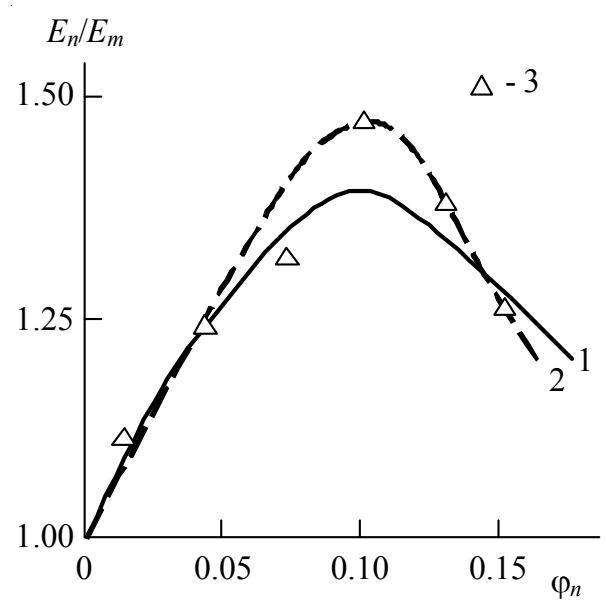

Fig. 4. The comparison of calculated according to the equation (1) with the use of the formulas (10) (1) and (13)

(2) for parameter $\alpha^{\mathrm{T}}$ determination and experimental (3) dependences of reinforcement degree $\mathrm{E}_{n} / \mathrm{E}_{m}$ on nanofiller volume content $\varphi_{n}$ for nanocomposites PVC-MMT

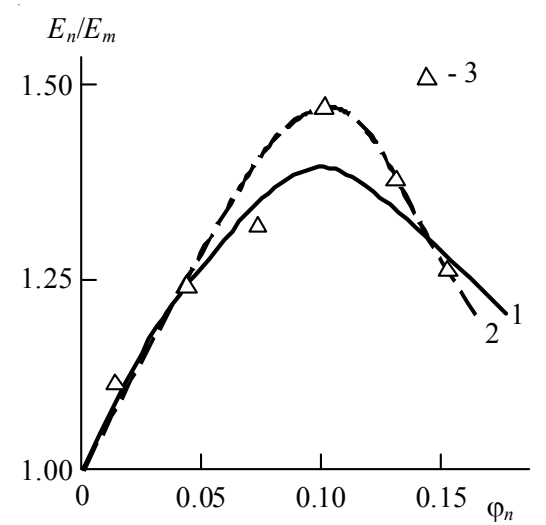

Fig. 5. The comparison of calculated according to the equation (1) at the condition of organoclay minimum aggregation (1) and experimental (2) dependences of reinforcement degree $\mathrm{E}_{n} / \mathrm{E}_{m}$ on nanofiller volume content $\varphi_{n}$ for nanocomposites PVC-MMT 


\section{ТЕХНИКО-ТЕХНОЛОГИЧЕСКИЕ ИННОВАЦИИ}

Forms and Applications. New York, Nova Science Publishers, 2008.

3. Kozlov G.V., Mikitaev A.K. Structure and Properties of Nanocomposites Polymer/Organoclay. Saarbrücken, LAP LAMBERT Academic Publishing GmbH and Comp., 2013.324 p.
4. Sheng N., Boyce M.C., Parks D.M., Rutledge G.C., Abes J.I., Cohen R.E. Multiscale Micromechanical Modeling of Polymer/Clay Nanocomposites and the Effective Clay Particle. Polymer, 2004, vol. 45, no. 2, pp. 487-506.

\section{АНАЛИТИЧЕСКОЕ ИССЛЕДОВАНИЕ АГРЕГАЦИИ ПРИ ПРОИЗВОДСТВЕ НАНОКОМПОЗИТОВ}

\section{Козлов Георгий Владимирович}

Старший научный сотрудник,

Кабардино-Балкарский государственный университет им. Бербекова

I_dolbin@mail.ru

ул. Чернышевского, 175, 360004 г. Нальчик, Российская Федерация

\section{Заиков Геннадий Ефремович}

Доктор химических наук, профессор, заведующий отделом биологической и химической физики полимеров,

Институт биохимической физики им. Н.М. Эмануэля РАН

chembio@sky.chph.ras.ru

ул. Косыгина, 4,119334 г. Москва, Российская Федерация

\section{Микитаев Абдулла Касбулатович}

Доктор химических наук, профессор,

Кабардино-Балкарский государственный университет им. Бербекова

I dolbin@mail.ru

ул. Чернышевского, 175, 360004 г. Нальчик, Российская Федерация

Аннотация. Целью настоящей работы является аналитическое исследование агрегации при производстве нанокомпозитов поливинилхлорида. Показано, что агрегации влияют на снижение доли нанонаполнителя и степень анизотропии. В свою очередь, этот фактор существенно снижает степень армирования нанокомпозитов. Показана роль межфазной адгезии в анизотропии определенного уровня.

Ключевые слова: нанокомпозит, агрегации, армирование, усиление степени анизотропии, межфазная адгезия. 